\title{
Review \\ Underground Diesel Exhaust Wet Scrubbers: Current Status and Future Prospects
}

\author{
Ahmed Adeeb Abdulwahid ${ }^{1,2}$, Rong Situ ${ }^{1, *}$ and Richard J. Brown ${ }^{3}$ \\ 1 College of Science and Engineering, James Cook University, Townsville, QLD 4811, Australia; \\ ahmed.abdulwahid@my.jcu.edu.au \\ 2 Engineering Department, AL-Nahrain University, Baghdad 10072, Iraq \\ 3 Biofuel Engine Research Facility, Queensland University of Technology, Brisbane, QLD 4001, Australia; \\ richard.brown@qut.edu.au \\ * Correspondence: rong.situ@jcu.edu.au; Tel.: +61-074-781-4172
}

Received: 20 September 2018; Accepted: 29 October 2018; Published: 1 November 2018

check for updates

\begin{abstract}
Diesel engines release a range of harmful components into the environment in the form of gases, liquids, and particulate matter (PM). These components have a direct and indirect impact on human health and climate change. Wet scrubbers are used to clean diesel exhaust emissions, by bubbling them through a liquid (usually water) to reduce their temperature and remove some soluble components and particles. Then, these emissions pass through a filter to remove further diesel particulate matter. The PM-capturing mechanism, heat transfer mechanism, and fluid mechanism of a wet scrubber are reviewed. Several parameters have a major influence on wet scrubber performance, such as inlet gas velocity. Modeling of a wet scrubber can be conducted through thermodynamics analysis, heat transfer analysis, and computational simulation. These investigations may lead to optimizing wet scrubber performance, and then to reducing both humidity and temperature at the scrubber exit. This humidity reduction increases filter life and reduces maintenance costs.
\end{abstract}

Keywords: wet scrubber; two-phase flow; particulate matter; diesel exhaust; underground mining; heat transfer

\section{Introduction}

Atmospheric air contains pollutants that have a short- and long-term effect on human health [1] and climate change such, as nitrogen dioxide (NOx), ground-level ozone $\left(\mathrm{O}_{3}\right)$, and particulate matter (PM). In 2015, nearly 39\% of nitrogen dioxides produced in the European Union was from the transportation sector. Significant nitrogen monoxide emissions [2] and 50\% of PM are generated by diesel engines [3]. To clarify, diesel engine emissions can be divided into gaseous precursors (NOx, $\mathrm{H}_{2} \mathrm{SO}_{4}, \mathrm{SO}_{3}, \mathrm{SO}_{2}, \mathrm{H}_{2} \mathrm{O}$, low-volatile, and semi-volatile organic compounds), and solid carbonaceous material such as PM [2-4].

PM is a suspended mixture in air, consisting of solid and liquid particles [5,6]. Its particles have different morphologies, sizes, and compositions. The diameter of PM can be measured using different methods based on their suitability. These methods are classified as: gravimetric, smoke opacity/smoke number, Laser Light Scattering Photometry (LLSP), Tapered Element Oscillating Microbalance (TEOM), and Scanning Mobility Particle Sizer (SMPS) [7]. Another measurement method was developed by Volkwein et al. [8] to estimate the PM from engines, based on the pressure increment across the dry filter. 
The characterization and chemical composition of PM depends on several engine parameters, such as rpm, load, type, lubrication oil, and age [9-12], as well as environmental factors, such as temperature, relative humidity, etc. [9]. For example, emission increases at low ambient temperature [13]. Furthermore, PM generation depends on fuel properties such as density, polyaromatic content, and the sulphur content [12-16].

Several techniques can be used to control these emissions, especially for underground engines. These comprise: low-emission fuel and engines [17], good ventilation, regular engine maintenance, effective filtration systems (for engine exhaust and operator cabin), and workforce education [18]. Special devices (connected with exhaust systems) can also be used to reduce these emissions, such as Diesel Particulate Filter (DPF), Engine Gas Recirculation (EGR), Selective Catalytic Reduction (SCR) systems, etc. One of these devices is a diesel engine exhaust wet scrubber, which is defined as an air pollution removal device that is fitted in a stream of exhaust gases, to eliminate PM and acid gases [19]. This scrubber has a high resistance to temperature and humidity. Moreover, it is small in size and can thus be fitted easily to the engine [20].

This paper aims to introduce and summarize the current status of the diesel exhaust wet scrubber and similar devices such as the bubble column. The paper will discuss the parameters which have a major effect on performance as well as ways to reduce the overall production costs and environmental pollution.

This article starts by reviewing the importance of pollution reduction from underground diesel engines. Secondly, the background section discusses the pollutant-capturing mechanisms in scrubbers, the heat transfer mechanism, and the flow mechanism in a bubble column (similar to a scrubber). Next, the effect of the governing parameters on wet scrubber performance is reviewed. This consists of the effect of inlet gas velocity, bubble size, particle density, liquid properties, and liquid volume. Subsequently, the performance of a wet scrubber is defined as the gas conditions at the scrubber exit and the scrubber removal efficiency. Finally, the modeling of a scrubber includes a thermodynamic approach and heat transfer modeling, where the correlations of bubble size, rising velocity, and heat transfer coefficients are explained in detail. Finally, computational simulation of the bubble column is briefly reviewed.

\section{Background}

Experts around the world have developed a range of studies concerning wet scrubber development, in order to reduce PM. Mainly, there are two types of wet scrubbers: those based on liquid droplets, and those based on gas bubbles. One example of a gas bubble based wet scrubber is the diesel exhaust wet scrubber. The diesel exhaust wet scrubber consists of an inlet exhaust gases pipe, with an outlet inserted beneath the water surface, as shown in Figure 1. The exhaust gas stream goes through the liquid, breaking into bubbles in different shapes and sizes, based on their velocities and locations. These air bubbles leave the water surface, then the scrubber, through the gas outlet towards the DPF, with a lower temperature and higher humidity than the inlet conditions. This design has several advantages, such as strong transfer (for heat and mass), and ease (for operation and construction). Moreover, the absence of moving parts leads to low maintenance costs [21], and reduced wear and tear [22]. To clarify, the DPF (also known as a particulate trap) is defined as a simple device where particles are trapped.

Wet scrubbers have various responsibilities, in particular, the elimination of sparks before they make contact with the surrounding environment, the filtration of PM, and the reduction of exhaust temperatures [7]. Furthermore, the wet scrubber is more effective than other types of scrubbers, even if it is relatively small. Moreover, it can be used for scrubbing different materials, including those that are sticky, hygroscopic, combustible, explosive, or corrosive. Therefore, it can be used in several engineering applications [19]. For instance, Gabriel et al. [23] converted a wet scrubber into a bio-trickling filter, by developing a ten-step procedure. Their experiments confirmed that a bio-trickling filter effectively removes $\mathrm{H}_{2} \mathrm{~S}$, regardless of its concentration. 


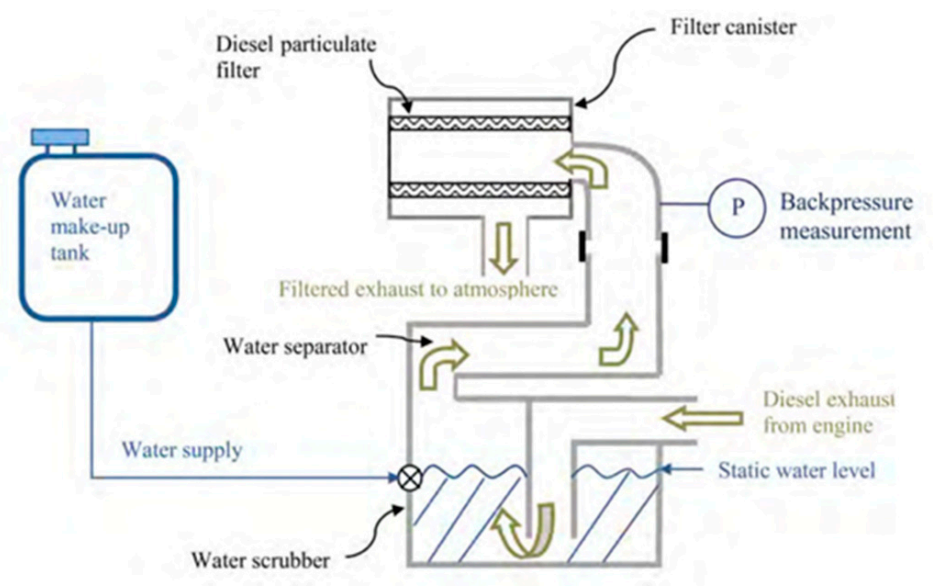

Figure 1. Schematic diagram of the diesel exhaust wet scrubber [7].

Although there are several positive aspects of wet scrubbers, they also have negative impacts. Firstly, the increased collection efficiency can lead to cost increments due to a pressure drop across the scrubber. Secondly, there are limits for both the temperature and the flow rate of exhaust gases. Moreover, a sludge waste is generated, which requires treatment or disposal. Another disadvantage is the presence of moisture in the gas stream, causing plume visibility or corrosion in the downstream system [19].

\subsection{Capturing Mechanisms of Pollutants in Wet Scrubbers}

The method of dissolving at least one component of a gas mixture into a liquid is called absorption, which is a feature of the wet scrubber. Two processes occur within this method. The physical process includes dissolving the components by solvent, which is controlled by the solvent and gas properties (viscosity and density), and the pollutant-specific temperature (equilibrium solubility and diffusivity depend on this). The chemical process represents the reaction between these components and the solvent. Most solvents are liquids, such as water, aqueous solutions, and some types of oils, namely, mineral and nonvolatile hydrocarbon. For economic feasibility, the solvent used to remove pollutants should be low in cost, viscosity and vapor pressure, and high in gas solubility. For this reason, water is considered to be the most suitable solvent for most applications [24].

Both chemical and physical processes increase if the contact area between the two phases increases. This contact area depends on bubble size at a constant gas flow rate. Passing gas through an orifice into a liquid pool leads to it breaking up into singular bubbles. Bubbles sizes and shapes are dependent on different factors, such as orifice (size and shape), fluid properties, and gas velocity. Bubble shapes can generally be classified into three different shapes: spherical, elliptical, and spherical cap. The transition from spherical to elliptical, and then to spherical cap, results from an increase in the gas flow rate within the system. Moreover, bubble size can also increase due to increasing orifice size, viscosity, and dissolving electrolyte concentration in the water. Bubble size decreases by decreasing surface tension by adding another liquid (such as alcohol) to water [25]. Furthermore, the liquid height above the orifice has a minor influence on bubble size [26]. 


\subsection{Heat Transfer Mechanism in Wet Scrubbers}

The design and operation principle of the wet scrubber is similar to the bubble column reactor. The bubble column reactor is a system containing a large number of gas bubbles, in direct contact with the continuum liquid. Moreover, the gas phase contains some soluble components, which are transferred to the liquid phase $[27,28]$. This reactor is suitable for various engineering applications [21]. These similarities concern flow type, analysis, gas inlet, and system types, as shown in Figure 2. To explain, Davidson \& Schüler [29] experimentally investigated the bubble formation at an orifice fitted inside a viscous liquid. Several forces limited both the bubble motion and their positions, such as drag, buoyancy, surface tension, and inertia. It was observed that these forces had various influences on the detaching bubble volume based on the gas volume flow rate. Increasing liquid density created smaller bubbles, and increased the bubble rising velocity.

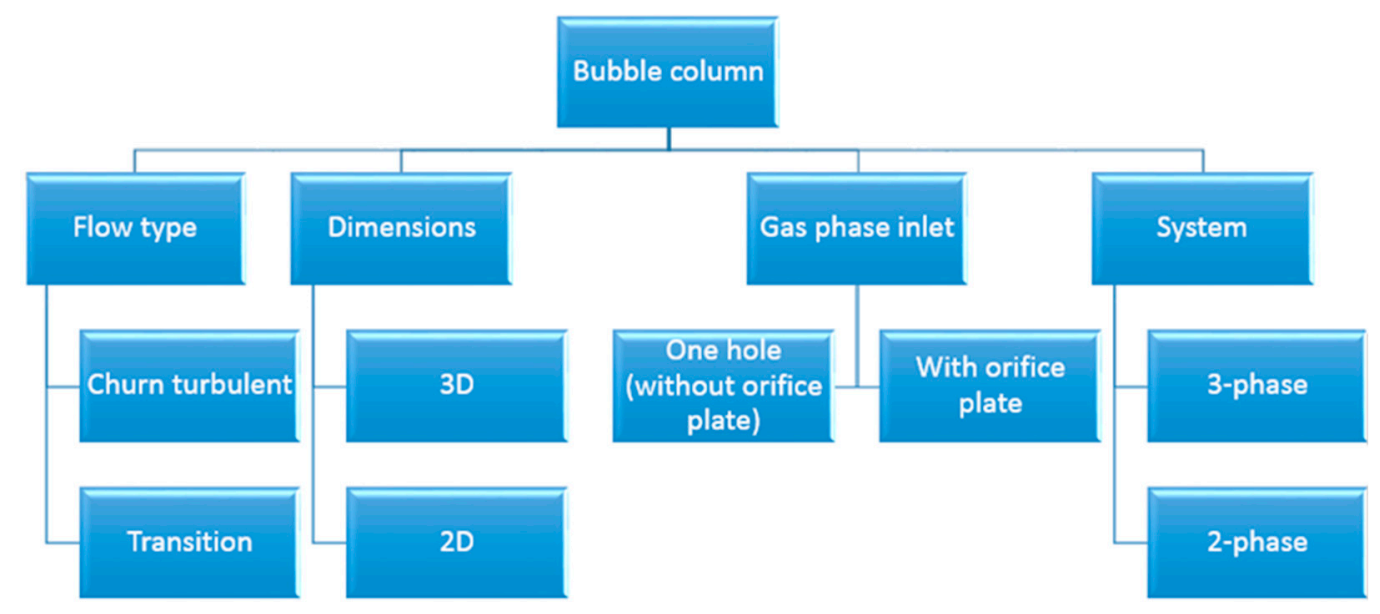

Figure 2. Laboratory investigation of bubble column.

Different types of heat transfer are found in wet scrubbers: evaporation, condensation, and convection. Evaporation occurs at the contact area between the liquid phase and the gas phase above. Condensation and boiling exist in most heat transfer cases of flowing fluid [30]. The phase changes from liquid to gas and vice versa, causing liquid evaporation, in addition to heat and mass transfer. The hydrodynamic behavior of the wet scrubber is also complex due to significant density compressibility differences in the fluid phases [19].

Heat transfer coefficients depend on multiple factors, in particular, the liquid properties (temperature variation changes the viscosity) and bubble size [31]. In other words, bubble motion depends mainly on this heat transfer rate and vice versa, due to direct interactions between bubbles and other structures within the fluid. Indeed, a high heat transfer rate could be achieved by adding particles to the liquid phase [32].

Gandhi and Joshi [33] analyzed the heat transfer coefficient of the bubble column. It was found that the Support Vector Regression (SVR) correlation was better than empirical and semi-empirical correlations, the main reason being that its prediction was more accurate and enhanced for different systems: gas-liquid, a large variety of operating pressures, a wide range of operating temperatures, most velocities of gas and liquid, different column diameters, and various liquid heights. Furthermore, Jhawar and Prakash [34] used fast response probes in a bubble column to study local heat transfer and dynamics. The authors claimed that this reactor should be operated in a heterogeneous regime, for high rates of achievement of heat transfer. 


\subsection{The Fluid Mechanism in Wet Scrubbers}

Three types of flow patterns have been observed in wet scrubbers: homogeneous (bubbly), transitional, and heterogeneous (churn-turbulent). Based on the operation conditions, the most frequently encountered flow regime is the churn-turbulent flow [22]. The flow pattern depends mainly on inlet gas velocity, scrubber diameter, the height to diameter ratio, and the nature of the gas-liquid system such as pressure, temperature, viscosity, surface tension, solid loading, orifice size, and preformation pitch $[22,35,36]$, as shown in Figure 3. This figure explains how increasing the inlet gas velocity changes the flow regime from bubbly to churn-turbulent, for a given scrubber size.

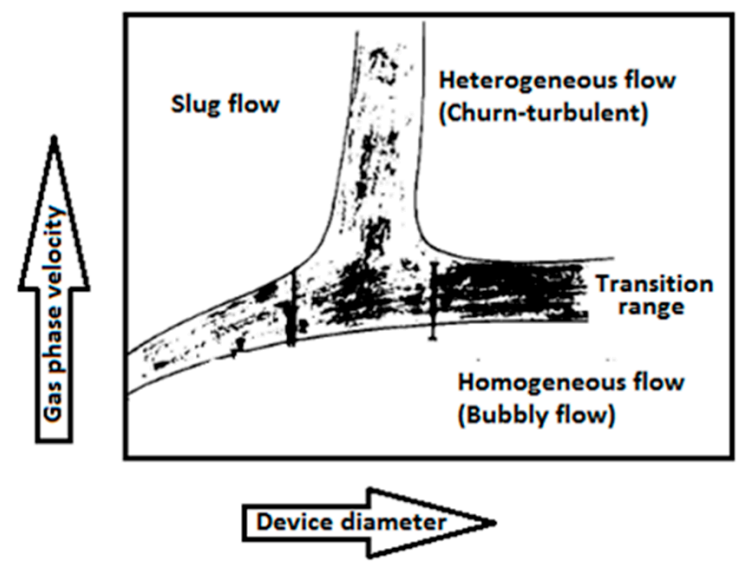

Figure 3. Characterizing the flow regimes in two-phase and slurry column reactors as a function of inlet gas velocity and scrubber dimension [36].

Each flow regime has hydrodynamic characteristics completely different from others, resulting in different mixing as well as mass and heat transfer rates. The homogeneous flow regime occurs at low-to-moderate inlet velocities of the gas phase. The characteristics of this regime are small bubbles of uniform size, traveling vertically with minor transverse and axial oscillations. There is a narrow bubble size distribution with no bubble breakup and coalescence. By comparison, heterogeneous flow occurs at high inlet velocities of the gas phase. Both small and large bubbles are generated in this flow regime, as a result of the intensity of coalescence and breakup, causing wide bubble size distribution. It is called a churn-turbulent regime because the large bubbles churn through the liquid. The slug flow regime occurs for small columns where bubble size becomes very close to column size when a void fraction is larger than $30 \%$ [22]. Up flow occurs in the central region of the bubble column, while down flow occurs near the walls in this flow type [35].

Various experimental techniques have been outlined by Shaikh and Al-Dahhan [22], to determine the flow regime transition, from bubbly flow to slug flow (due to bubble coalescence), in the bubble column. Also, in their worthwhile review Besagni et al. [28] explained in detail all the possible flow regimes in the bubble column and which parameters could affect it. For example, flow characteristics might be measured using various techniques such as the photographic method [5], X-ray [7], PIV [10,37], optical fiber probe [38], conductivity probe [39], pressure transducer [20,40-42], electrical capacitance tomography [43], and acoustic probe [44,45]. 


\section{The Governing Parameters of Wet Scrubbers}

The interrelated bubble parameters, such as bubble velocity, gas-liquid interfacial area, and bubble frequency, have a major influence on wet scrubber performance. Other factors affecting scrubber performance include scrubber design (geometry and size), operation condition (flow rates, temperatures, pressures), and physical properties [19]. Furthermore, particle changes (coagulation and volatility) could occur as a result of their passing through the exhaust system, after passing through the engine cylinders [46]. Moreover, the amount of water (high or low) in addition to equipment could affect wet scrubber performance [38]. Most importantly, dimensionless numbers can be used to describe the flow and heat transfer mechanisms, to make the equation independent of the specific equipment shape or size, viscosity, density, and so forth. Seven different dimensionless numbers can be investigated in wet scrubber performance, namely: $\mathrm{Bo}, \mathrm{Ec}, \mathrm{Nu}, \mathrm{Pr}, \mathrm{Re}, \mathrm{St}$, and We. For these reasons, any study of wet scrubber performance should consider all the related parameters.

\subsection{The Effect of Inlet Gas Velocity}

A change in gas volume flux has a significant effect on wet scrubber performance [7]. It was found that $19 \%$ absorption of carbon dioxide was caused by increasing the gas flow rate. Another $10 \%$ to $14 \%$ increment of absorption was achieved by heating carbon dioxide, which was based on the heat energy generated from the reaction between water and carbon dioxide. Under a certain amount of hydrogen chloride $(\mathrm{HCl})$ concentration, increasing the inlet gas flow rate would result in a reduction in $\mathrm{HCL}$ removal [37]. Therefore, choosing a wet scrubber size depends mainly on the exhaust gas flow rate, as it limits the amount of scrubbing liquid [38].

Increasing the inlet gas velocity increases the mixing of the liquid phase, reduces bubbles size due to high bubble breakup [21], and leads to wider bubble size distribution [40]. Nevertheless, at low inlet gas velocities, bubble breakup and coalescence were weak, in addition to a narrow distribution being observed [40]. However, the excessive turbulence and high inlet gas flow rate lead to more water ejection at the scrubber exit. This could result in damages to the post-scrubber diesel particulate filter, in addition to increasing the maintenance time required [39]. Usually, diesel equipment for underground mining operates in continually varied operating conditions. Therefore, all these parameters can be expected.

\subsection{The Effect of Bubble Size}

Wet scrubber performance is dependent on bubble size because a larger bubble surface area transfers more heat. As a case in point, Higuera and Medina [41] investigated bubble generation and coalescence in quiescent inviscid liquid, using the formulation of potential flow. A constant gas flow rate was injected vertically upward into the liquid. Their results show that bubbles have a constant volume at a low Weber number because bubble growth depends on inertia and buoyancy forces. At a high Weber number, on the other hand, this growth was led by the interaction among the bubbles. Moreover, increasing the inlet gas velocity reduces the average bubble diameter [47]. Conversely, bubble size could be reduced as a result of a pressure increment [43]. In a wet scrubber, the gas phase is injected underneath the liquid-phase surface at a non-constant rate, so the bubbles have non-uniform shapes with the continuous breakup and coalescence. Thus, investigating this particular parameter is extremely complex. 


\subsection{The Effect of Particle Density}

PM loading is known as dust loading, and it is defined as the mass of PM per unit volume at the scrubber inlet. Removal efficiency decreases as the fly-ash loading increases [47]. Furthermore, Guo and Gao [48] used a wet scrubber to remove both $\mathrm{SO}_{2}$ and $\mathrm{NO}_{2}$; using limestone slurry including several operating parameters, namely, the reaction temperature, oxygen amount in flue gas, and inlet concentration of $\mathrm{SO}_{2}$ and $\mathrm{NO}_{2}$. It was found that minimizing the concentration of the inlet $\mathrm{NO}_{2}$, the amount of $\mathrm{O}_{2}$ in the flue gas, and the reacting temperature, caused a reduction in the removal efficiency of $\mathrm{SO}_{2}$. Nevertheless, the absorption of $\mathrm{NO}_{2}$ was increased due to increasing the concentration of the inlet $\mathrm{SO}_{2}$ and reducing the reaction temperature and the flue gas oxygen. Furthermore, the collection efficiency depends on the particle size. Therefore, higher efficiency could be achieved with large particle sizes [19,47]. In summary, for underground diesel equipment, PM depends on fuel type [14] and equipment operating conditions.

\subsection{The Effect of the Liquid Thermal Properties on Pollutant Removal}

Pollutant diffusion occurs when the liquid has less pollution than the gaseous component [24]. For instance, Bhadra et al. [49] experimentally tested a wet scrubber, using a water solution and other components to collect solid particles. Their experiments were conducted by wetting solid particles through direct contact with the liquid. After absorption, the solid particles were dissolved in the liquid or created a colloidal form that settled down. It was observed that mixing carbonate of calcium (limestone) with exhaust gases from the engine gave a higher emission reduction. In another example, Talaia [44] experimentally tested the bubble rising velocity in a single column using two different liquids (water and glycerol). It was confirmed that this velocity depends mainly on drag force rather than buoyancy.

The most suitable absorption liquid can be chosen after considering several factors, particularly availability, cost, pollutant concentrations, removal efficiency, requirements for handling exhaust gas capacity, and the recovery value of pollutants. Adding coolants such as urea $\left(\left(\mathrm{NH}_{2}\right)_{2} \mathrm{CO}\right)$ to the scrubbing liquid will increase its boiling temperature and life. Indeed, the removal efficiency increases for a limited time [49]. Therefore, it is key to consider this effect in any underground diesel exhaust wet scrubber investigation.

\subsection{The Effect of Liquid Volume}

High water levels in the wet scrubber lead to a 25\% reduction in PM emissions [11]. However, increasing the water level inside the scrubber also leads to more water exiting [45]. The investigation of underground diesel exhaust wet scrubber performance should consider this factor to determine which one of these two options is more important.

\section{Performance Parameters}

\subsection{Scrubber Outlet Conditions (Particularly Temperature and Humidity)}

Lowering the exhaust gas temperature is the main role of the wet scrubber. Its lesser role is to eliminate the sparking possibility at the exhaust [42]. Indeed, increasing the outlet gas temperature reduces the corresponding relative humidity. Equally importantly, the water evaporation causes most of the water transportation from the scrubber. This evaporation depends on the inlet gas-phase temperature, while a low amount of water leaves the scrubber due to the aerodynamic process. Another $2-8 \%$ water generates from the combustion, and is carried by exhaust gas. This percentage is not constant; it is affected by both engine load and speed [7]. Exit temperature and relative humidity increase with operation time, and any type of thermal energy leaving or entering the scrubber depends on engine rpm. The increment in the absolute humidity was also found to occur at a high evaporation rate [22]. 


\subsection{Removal Efficiency}

The removal efficiency depends strongly on the scrubber configuration and the scrubbing liquid [42]. It is defined as the number of molecules of a compound removed or destroyed in a system relative to the number of molecules that entered the system:

$$
\eta=\frac{C_{i n}-C_{o u t}}{C_{i n}}
$$

where: $C_{i n}$ is the concentration of any component that enters the system, and $C_{\text {out }}$ is the concentration of any component that leaves the system.

Or [50]:

$$
\text { filtertion efficiency }=\frac{\text { Particles downstream trap }}{\text { Particles upstream trap }} \times 100 \% \text {. }
$$

Researchers have studied this parameter extensively to reduce the emission at the scrubber exit. For instance, Tokumura et al. [51] effectively removed indoor air pollutants using a wet scrubber coupled with the photo-Fenton reaction. To clarify, this reaction consists of a series of chain reactions between $\mathrm{H}_{2} \mathrm{O}_{2}$ at acidic value and $\mathrm{Fe}(\mathrm{II}) / \mathrm{Fe}$ (III) [52]. Indeed, the high increment in removal efficiency was achieved using this technique [53,54]. Also, D'Addio et al. [55] experimentally tested an electronic wet scrubber by spraying tap water to remove both fine and ultrafine particles from combustion gases. By system charging, there was an increment of approximately $30 \%$ achieved in removal efficiency. Therefore, the hydrodynamic interaction was less effective than electrostatic interaction. More importantly, high removal efficiency is achieved due to bubbles bursting [27].

\section{Wet Scrubber Models}

\subsection{A Thermodynamic Model of the Diesel Exhaust Wet Scrubber}

An energy balance can be applied to a wet scrubber with thermodynamic analysis. It balances inlet and outlet masses, in addition to inlet and outlet energies, as shown in Figure 4 [39]:

$$
\dot{E_{i n}}=\dot{E_{o u t}}+\dot{E_{\Delta v}}+Q_{L}+\dot{E_{w}},
$$

where: $\dot{E}_{\text {in }}$ is the inlet energy of exhaust gases from the diesel engine $(\mathrm{kW}), E_{\text {out }}^{\cdot}$ is the outlet energy leaving the scrubber from its exit $(\mathrm{kW}), E_{\Delta v}$ is the lost energy because of the water volume changing (due to evaporation) (kW), $Q_{L}$ is the heat transfer from the scrubber to the surrounding environment through all of its sides $(\mathrm{kW})$, and $\dot{E}_{w}$ is the amount of storage energy inside the scrubber $(\mathrm{kW})$.

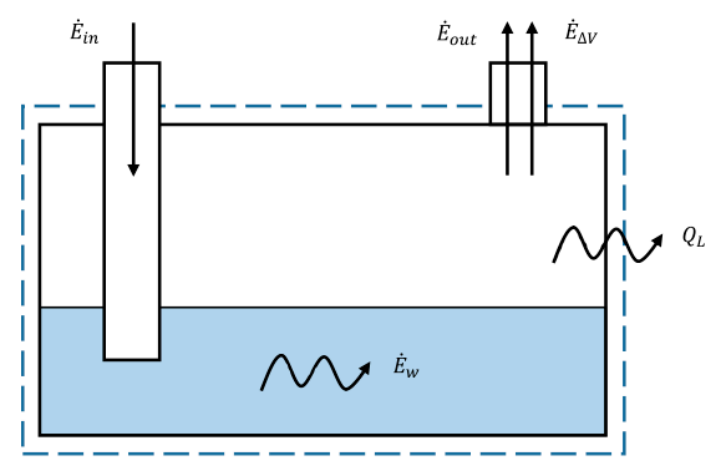

Figure 4. Energy balances for wet scrubber [39]. 
The calculations of inlet energies and outlet energies would be based on the components of the exhaust gases, which consist of carbon dioxide, water vapor, oxygen, and nitrogen, as shown in Equation (4):

$$
\mathrm{C}_{12} \mathrm{H}_{23}+26.625\left(\mathrm{O}_{2}+3.76 \mathrm{~N}_{2}\right)=12 \mathrm{CO}_{2}+11.5 \mathrm{H}_{2} \mathrm{O}+8.875 \mathrm{O}_{2}+100.11 \mathrm{~N}_{2} .
$$

Therefore, inlet energy consists of the inlet energy of each component as:

$$
\dot{E_{i n}}=\left(m_{\mathrm{CO}_{2}} c_{p_{\mathrm{co}_{2} i n}} T_{i n}\right)+\left(\dot{m_{\mathrm{H}_{2}} \mathrm{O}} c_{p_{\mathrm{H}_{2} \mathrm{O} i n}} T_{i n}\right)+\left(\dot{m_{\mathrm{O}_{2}}} c_{p_{\mathrm{O}_{2} i n}} T_{i n}\right)+\left(\dot{m_{\mathrm{N}_{2}}} c_{p_{\mathrm{N}_{2} i n}} T_{i n}\right)
$$

Similarly, the outlet energy from the wet scrubber exit represents the entire mixture:

$$
\dot{E_{\text {out }}}=\left(m_{\mathrm{CO}_{2}} c_{p_{\mathrm{co}_{2} \text { out }}} T_{\text {out }}\right)+\left(m_{\mathrm{H}_{2} \mathrm{O}} c_{p_{\mathrm{H}_{2} \text { Oout }}} T_{\text {out }}\right)+\left(\dot{m_{\mathrm{O}_{2}}} c_{p_{\mathrm{o}_{2} \text { out }}} T_{\text {out }}\right)+\left(\dot{m_{\mathrm{N}_{2}}} c_{\mathrm{N}_{2} \text { out }} T_{\text {out }}\right),
$$

where: $m$ is the mass flow rate $(\mathrm{kg} / \mathrm{s}), c_{p_{i n}}$ is the specific heat capacity at the scrubber inlet temperature $(\mathrm{kJ} / \mathrm{kg} \cdot \mathrm{K}), c_{p_{\text {out }}}$ is the specific heat capacity at the scrubber outlet temperature $(\mathrm{kJ} / \mathrm{kg} \cdot \mathrm{K}), T_{\text {in }}$ is the temperature at the scrubber inlet $(\mathrm{K})$, and $T_{\text {out }}$ is the temperature at the scrubber exit $(\mathrm{K})$.

Moreover, by combining the energy loss due to water evaporation, with the liquid phase that is leaving the wet scrubber because it is carrying some energy, the energy loss due to changing water volume is calculated by:

$$
\dot{E_{\Delta v}}=\left(m_{w_{\text {out }}}^{\dot{ }}-\dot{m}_{w_{\text {in }}}\right)\left(h_{f g}+c_{p_{f}}\left(T_{\text {out }}-T_{w}\right)\right)+\left(\frac{d W}{d t}-m_{w_{\text {out }}}^{\dot{ }}+m_{w_{\text {in }}}\right)\left(c_{p_{f}}\left(T_{\text {out }}-T_{\text {in }}\right)\right),
$$

where: $h_{f g}$ is the water vaporisation latent heat $(\mathrm{kJ} / \mathrm{kg}), \frac{d W}{d t}$ is the water mass change rate $(\mathrm{kg} / \mathrm{s})$, and $c_{p_{f}}$ is the liquid specific heat capacity $(\mathrm{kJ} / \mathrm{kg} \cdot \mathrm{K})$.

Water temperature increases as a result of heat transfer from inlet gases, and this energy stores in water, therefore, it can be calculated as:

$$
\dot{E_{w}}=m_{w} c_{p_{w}} \frac{d T_{w}}{d t}
$$

where $\frac{d T_{w}}{d t}$ is the water temperature changing rate $(\mathrm{K} / \mathrm{s})$.

The heat loss through the scrubber body can be calculated as:

$$
Q_{L}=\left(\% A_{\text {above }} m_{\text {scrub. }} c_{p_{\text {scrub. }}} \frac{d T_{\text {above }}}{d t}\right)+\left(\% A_{\text {below }} m_{\text {scrub. }} c_{p_{\text {scrub. }}} \frac{d T_{\text {below }}}{d t}\right)+\left(m_{w} c_{p f} \frac{d T_{w_{\text {heat loss }}}}{d t}\right),
$$

where $\% A$ is the scrubber surface area percentage, above or below the liquid surface, and scrub. refers to the scrubber.

The enthalpy-based calculation is another method to calculate the energies instead of heat capacity mentioned in Equations (5)-(7). Finally, the liquid balance technique calculates the evaporation rate through the scrubber, as follows:

$$
E=m_{w_{\text {in }}}-m_{\dot{w}_{\text {out }}}-\frac{d W}{d t}
$$

where $E$ is the evaporation rate $(\mathrm{kg} / \mathrm{s}), m_{w_{\text {in }}}$ is the average inlet liquid mass flow rate $(\mathrm{kg} / \mathrm{s})$, and $m_{w_{\text {out }}}$ is the average outlet liquid mass flow rate $(\mathrm{kg} / \mathrm{s})$.

\subsection{Bubble Heat Transfer Model}

Heat transfer analysis of the wet scrubber should directly investigate the bubbles in the scrubber, their formation mechanism, variation of growth with time and height, and finally the heat transfer mechanism between the bubbles and their surrounding liquid. 
The bubble heat transfer coefficient greatly depends on the two-phase flow regime [36,56]. One of the several classifications of two-phase mixtures is based on their combinations of gas, liquid, and solid phases, in addition to the possibility of plasma. In a diesel exhaust wet scrubber, all these types exist except the plasma. Furthermore, variations in the two-phase flow occur due to phase combinations and varied interface structures [57].

For a thorough investigation, the influence of all forces acting on bubbles must be considered. Single bubbles do not exist in wet scrubbers, due to the nature of the high gas-phase flow rate. However, the heat transfer model of a wet scrubber could begin by studying a single bubble, then expanding to multiple bubbles with various sizes and shapes.

Forces that affect the bubble vertically are drag force, buoyancy, virtual mass force, and gravity $[36,58,59]$. These forces equal bubble mass multiplied by its acceleration, according to Newton's second law of motion, as follows:

$$
m \cdot a=P+F_{D}+F_{V}+F_{G}
$$

where $P$ is the pressure force, $F_{D}$ is the drag force, $F_{V}$ is the virtual mass force, $F_{G}$ is the gravity force, and all in $(\mathrm{N}), m$ is the bubble mass $(\mathrm{kg})$, and $a$ is the bubble acceleration $\left(\mathrm{m} / \mathrm{s}^{2}\right)$.

Pressure forces direct an object upward in liquid, due to the pressure difference between the top and the bottom of that object. It is equal to the fluid weight displaced by the body:

$$
P=G_{l}=\rho_{l} g V_{\mathrm{b}}
$$

where $V_{\mathrm{b}}$ is the bubble volume $\left(\mathrm{m}^{3}\right)$.

The liquid resistance to bubble movement is called drag force, and it can be calculated as:

$$
F_{D}=-\frac{1}{2} \rho_{l} C_{D}\left|u_{l}-u_{g}\right|\left(u_{g}-u_{l}\right) s_{a},
$$

where $C_{D}$ is the drag coefficient due to drag force, and $s_{a}$ is the bubble front face area $\left(\mathrm{m}^{2}\right)$.

Rising bubbles accelerate the surrounding liquid and generate another virtual mass force. This force increases inertial mass effectiveness, and interrupts the continuous phase acceleration. However, the virtual mass force could be neglected if the dispersed phase density far outweighs the continuous phase:

$$
F_{V}=\frac{1}{2} V_{\mathrm{b}} \rho_{l} \frac{d}{d t}\left(u_{l}-u_{g}\right)
$$

Finally, the gravity force is calculated as:

$$
F_{G}=-m_{\mathrm{b}} g=-\rho_{g} V_{\mathrm{b}} g
$$

\subsubsection{Bubble Size}

Bubble motion depends mainly on its volume [58]. Therefore, it is important to investigate this factor to improve wet scrubber performance. Indeed, bubble volume is calculated from the force balance mentioned in the previous section. On the other hand, the gas flow rate has no effect on bubble volume in a static regime (at a small gas flow rate), due to neglecting the two-phase momentums. In the turbulent regime, large bubbles shatter into small ones, because they cannot survive against the gas turbulence [59]. Table 1 demonstrates some correlations of both dimensional and non-dimensional bubble diameter. This table could be valuable for bubble diameter estimation in a scrubber. In particular, the correlation proposed by Levich [60] concerns a churn-turbulent regime, and that developed by Martinez-Bazan et al. [61] concerns turbulent flow. At a constant inlet gas velocity, Davidson and Schuler's equation [62] could calculate bubble diameter without including the fluid properties. Bubble shape can be assumed to be spherical or elliptical based on the flow type. 
Table 1. Bubble size correlations.

\begin{tabular}{|c|c|c|c|}
\hline No. & Author/Researcher & Correlation & Condition/Technique \\
\hline 1 & Leibson et al. (1956) [63] & $d_{b}=0.28 \mathrm{Re}^{-0.05}$ & $\begin{array}{l}\text { Departure bubble diameter from a single orifice in } \\
\text { turbulent flow } \operatorname{Re}>10,000 \text {. }\end{array}$ \\
\hline 2 & $\begin{array}{l}\text { Davidson and Schüler } \\
\text { (1960) [62] }\end{array}$ & $d_{b}=1.3 \frac{Q_{8}^{\prime \frac{2}{5}}}{g^{\frac{1}{5}}}$ & $\begin{array}{l}\text { For a constant flow rate at the orifice without including } \\
\text { the inviscid liquid properties and surface. }\end{array}$ \\
\hline 3 & Levich (1962) [60] & $d_{\max } \approx \frac{3.63 \sigma}{u_{b}^{2} \sqrt[3]{\rho_{l}^{2} \rho_{g}}}$ & Churn-turbulent flow regime. \\
\hline & & & $\begin{array}{l}\text { When the diameter of the orifice is comparable with the } \\
\text { radius of the bubble, that is }\end{array}$ \\
\hline 4 & Wallis (1969) [64] & $d_{b}=\left[\frac{6 d_{o} \sigma}{\mathrm{g}\left(\rho_{f}-\rho_{g}\right)}\right]^{\frac{1}{3}}$ & $d_{0}>\left[\frac{\sigma}{\mathrm{g}\left(\rho_{f}-\rho_{g}\right)}\right]^{\frac{1}{2}}$ \\
\hline 5 & $\begin{array}{l}\text { Moalem and Sideman } \\
\text { (1973) [65] }\end{array}$ & $\begin{array}{l}\beta=\left[1-\frac{3}{2}\left(\frac{k_{v}}{\pi}\right) \tau\right]^{\frac{2}{3}} \\
\beta=\left[1-\frac{5}{4}\left(\frac{k_{v}}{\pi}\right)^{\frac{1}{2}} \tau\right]^{\frac{4}{5}}\end{array}$ & $\begin{array}{l}\text { Combining the effect of bubble rising velocity and } \\
\text { mainstream cross flow to investigate the collapse for } \\
\text { pure vapor and at constant bubble velocity. } \\
\text { The 1st correlation is for a bubble diameter of } 0.4-0.8 \mathrm{~cm} \text {. } \\
\text { The 2nd correlation is for a bubble diameter of less than } \\
0.2 \mathrm{~cm} \text {. }\end{array}$ \\
\hline 6 & Anagbo (1991) [66] & $V_{b}=0.7\left[\frac{\rho_{g}}{\rho_{f}}\right]^{-\frac{1}{4}}\left[\frac{d_{0}}{2 g}\right]^{\frac{1}{2}} Q_{g}^{\prime}$ & Ellipsoidal bubble formation at free-standing nozzle. \\
\hline 7 & $\begin{array}{l}\text { Martínez-Bazán et al. } \\
\text { (1999) [61] }\end{array}$ & $d_{\text {max }}=\left[\frac{12 \sigma}{\beta^{\prime} \rho_{l}}\right]^{\frac{3}{5}} \varepsilon^{-\frac{2}{5}}$ & $\begin{array}{l}\text { The breaking up of injected bubbles into fully developed } \\
\text { turbulent flows based on Kolmogorov's concept. }\end{array}$ \\
\hline 8 & $\begin{array}{l}\text { Lehr and Mewes } \\
\text { (2001) [67] }\end{array}$ & $d_{\max }=2 \frac{1}{5} \frac{\sigma^{\frac{3}{5}}}{\rho_{l}^{\frac{3}{5}} \varepsilon^{\frac{2}{5}}}$ & Following the idea of Levich [60]. \\
\hline 9 & Zhang et al. (2008) [68] & $d_{b}=\sqrt[3]{\frac{6 Q_{g}^{\prime}}{\pi n}}$ & $\begin{array}{l}\text { The unsteady motion of single bubbles rising freely in a } \\
\text { quiescent high viscous liquid. } \\
\text { The volumetric gas rate and the number of generated } \\
\text { bubbles per unit time were used to calculate the bubble } \\
\text { volume based on spherical shape assumption. }\end{array}$ \\
\hline
\end{tabular}

\subsubsection{Bubble Rising Velocity}

The rising velocity of a single bubble depends on buoyancy and drag forces, which are functions of gravity, fluid properties, and equivalent diameters. Dynamic viscosity has a strong effect on terminal velocity [44]. The bubble acceleration affects the total drag coefficient [68]. Similarly, a slip occurs at the liquid-vapor interface, and the liquid cleanliness can be determined by measuring small bubbles [69]. Also, bubble velocity increases due to the bubble size increment. Moreover, the bubble drag coefficient and aspect ratio decrease with an increasing Reynolds number [70]. For more details, Table 2 shows several correlations to predict bubble rise velocities. It contains some of the most widely used correlations [71]. Indeed, some correlations should be examined carefully for their suitability for a wet scrubber, especially those on Line 3-5, and 8 in Table 2. For this purpose, three-dimensional bubble movement should be considered to achieve more accurate results. 
Table 2. Bubble rising velocity correlations.

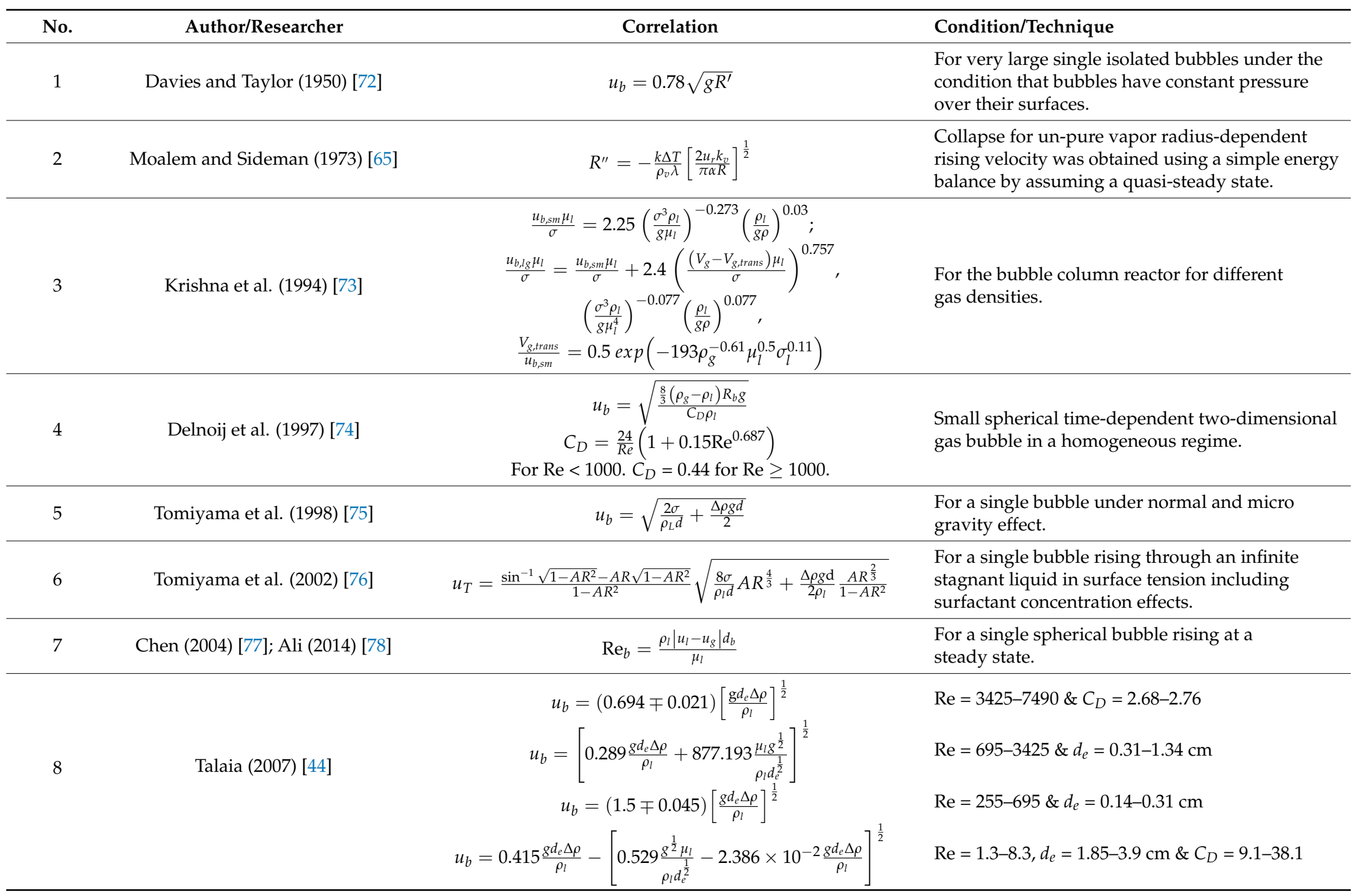




\subsubsection{Bubble Heat Transfer}

Bubble heat transfer rate is influenced by various factors, such as bubble size, bubble orientation, temperature, and the physical properties of both gas and liquid phases [33]. Heat transfer increases with increasing gas-phase inlet velocity, and working pressure [43]. Simply, the heat transfer can be calculated from the energy balance at the interface of the bubble, by assuming the bubble to have a spherical shape; it can be expressed mathematically as [29]:

$$
\left(-q^{\prime \prime}\right)\left(4 \pi R^{2}\right)=\left(\rho_{g} h_{f g}\right)\left(\frac{d V_{b}}{d t}\right)
$$

Subsequently, the heat transfer coefficient can be calculated from correlation [79]:

$$
h_{c}=\frac{-k\left(\frac{\partial T}{\partial y}\right)_{W}}{T_{W}-T_{\infty}} .
$$

The heat transfer coefficient can become more complex during rising motion, so [79]:

$$
h_{c}=-\frac{\rho_{g} h_{l g} V_{b}}{\frac{1}{2} A_{b}\left(T_{W}-T_{\infty}\right) t_{k}}
$$

where $h_{c}$ is the heat transfer coefficient, and $t_{k}$ is the condensation time (s).

Moreover, the heat transfer can be calculated using other correlations. Some of them were reported by Reference [33], as explained in Table 3. The most suitable correlations for wet scrubbers are the Line 6-7, 9 and $14-15$ of Table 3 due to flow and system similarities. 
Table 3. Heat transfer correlations.

\begin{tabular}{|c|c|c|c|c|}
\hline No. & Author/Researcher & System & Correlation & Conditions \\
\hline 1 & Fair et al. (1962) [80] & Air-water & $h_{c}=1200 u_{b}^{0.22}$ & $\begin{array}{l}\text { For vessel sizes equal to or more than } 18^{\prime \prime} \\
\text { and superficial gas velocity }=0-0.5 \mathrm{ft} \text {. } / \mathrm{s} \text {. }\end{array}$ \\
\hline 2 & $\begin{array}{l}\text { Mikic and Rohsenow } \\
\text { (1969) [81] }\end{array}$ & & $\begin{array}{l}q=\frac{2 k \Delta T \sqrt{n_{b}}}{\sqrt{\pi \alpha}} \\
\left(\frac{q}{A}\right)_{n c}=0.54 \rho_{l} c_{p l}\left[\frac{\gamma g\left(T_{W}-T_{\infty}\right)^{5} \alpha^{3}}{\sqrt{A_{\text {total }} v}}\right]^{\frac{1}{4}} \\
\left(\frac{q}{A}\right)_{n c}=0.14 \rho_{l} c_{p l}\left[\frac{\gamma g\left(T_{W}-T_{\infty}\right)^{4} \alpha^{2}}{v}\right]^{\frac{1}{3}}\end{array}$ & $\begin{array}{l}\text { For pool boiling with heating surface. } \\
\text { The } 2 \text { nd correlation is for pool boiling in a } \\
\text { laminar range } 10^{5}<\mathrm{Ra}<2 \times 10^{7} \text {. } \\
\text { The 3rd correlation is for pool boiling in a } \\
\text { turbulent range } 2 \times 10^{5}<\mathrm{Ra}<3 \times 10^{10} \text {. }\end{array}$ \\
\hline 3 & $\begin{array}{l}\text { Moalem and Sideman } \\
\quad(1971) \text { [82] }\end{array}$ & Non-homogenous distribution & $\begin{array}{c}q=q_{o} \sqrt{K_{v}}, \\
q_{o}=\frac{k\left(T_{W}-T_{\infty}\right)}{R \sqrt{\pi}} \sqrt{\frac{2 R U_{\infty}}{\alpha}}, \\
K_{v}=0.25 \operatorname{Pr}^{-\frac{1}{3}}\end{array}$ & For bubble condensation. \\
\hline 4 & $\begin{array}{l}\text { Theofanous and } \\
\text { Fauske (1973) [83] }\end{array}$ & Liquid-metal vapor & $\begin{array}{r}q=k_{l} \sqrt{\frac{2 U_{\infty}}{\pi \alpha_{l} R}}\left(T_{W}-T_{l \infty}\right) \\
Q=4 \pi R^{2} q=4 k_{l} \sqrt{\frac{2 \pi U_{\infty} R^{3}}{\alpha_{l}}}\left(T_{W}-T_{l \infty}\right)\end{array}$ & $\begin{array}{l}\text { For single large vapor bubble. } \\
\text { condensation in a cool liquid. }\end{array}$ \\
\hline 5 & $\begin{array}{l}\text { Moalem and Sideman } \\
\quad(1973)[65]\end{array}$ & & $\mathrm{Nu}=\frac{2}{\sqrt{\pi}}\left(k_{v} \mathrm{Pe}\right)^{\frac{1}{2}}$ & $\begin{array}{l}\text { For a single bubble in a single and } \\
\text { two-component system, either pure or } \\
\text { containing non-condensable. }\end{array}$ \\
\hline 6 & Hart (1976) [84] & Air-water, Air-ethylene & $h_{c} \propto \frac{u_{b}^{0.25} g^{0.25} \rho^{0.75} c_{p}^{0.4} k^{0.6}}{\mu^{0.35}}$ & $\begin{array}{l}\text { For bubble-agitated system with } \\
\text { Us }>0.00159 \mathrm{ft} / \mathrm{s} \text {. }\end{array}$ \\
\hline 7 & $\begin{array}{l}\text { Ozisik and Kress } \\
\quad(1978)[85]\end{array}$ & $\begin{array}{l}\mathrm{UO}_{2} \text { \& Sodium vapors containing } \\
\text { non-condensable fission gases }\end{array}$ & $\begin{array}{l}h_{c}(t)=\frac{q(t)}{T_{\infty}-T_{W}(t)} \\
Q_{0 \rightarrow t} \cong\left(T_{\infty}-T_{W}(t)\right) h_{c} t\end{array}$ & $\begin{array}{l}\text { Large rising vapor-gas bubble } \\
\text { condensation in a hypothetical core. }\end{array}$ \\
\hline 8 & $\begin{array}{l}\text { Deckwer et al. } \\
\text { (1980) [25] }\end{array}$ & $\begin{array}{l}\text { Nitrogen-xylene, Kogasin, decalin, } \\
\text { nitrogen-paraffin-powdered } \mathrm{Al}_{2} \mathrm{O}_{3}\end{array}$ & St $=0.1\left[\left(\operatorname{ReFrPr}^{2}\right)^{-0.25}\right]$ & $\begin{array}{l}\text { Based Kolmogoroffs theory of isotropic } \\
\text { turbulence and } u_{\mathrm{r}}=0.003-0.04 \mathrm{~m} / \mathrm{s} \text {. }\end{array}$ \\
\hline 9 & Hikita et al. (1981) [86] & $\begin{array}{l}\text { Air-water } \\
\text { Air-butanol } \\
\text { Air-sucrose } \\
\text { methanol }\end{array}$ & $\begin{array}{l}h_{c}=0.411 g^{0.308} u_{g}^{0.149} c_{p}^{0.333} k^{0.667} \rho^{0.692} \mu^{-0.286} \sigma^{-0.073} \\
\frac{h_{c}}{\rho_{l} u_{g} c_{p}}\left(\frac{c_{p} \mu_{l}}{k}\right)^{0.66}=0.268\left(\frac{u_{g}^{3} \rho_{l}}{\mu_{l} g}\right)^{-0.303}\end{array}$ & $\begin{array}{l}\text { 1st condition } \\
5.4 \times 10^{-4}<\frac{u_{g} \mu}{\sigma}<7.6 \times 10^{-2} \\
\text { 2nd condition } 4.9<\frac{c_{\mathrm{p}} \mu}{k}<93 \\
\text { 3rd condition } \\
7.7 \times 10^{-12}<\frac{\mu^{4}}{\rho \sigma^{4}} g<1.6 \times 10^{-6}\end{array}$ \\
\hline
\end{tabular}


Table 3. Cont.

\begin{tabular}{|c|c|c|c|c|}
\hline No. & Author/Researcher & System & Correlation & Conditions \\
\hline 10 & Saxena (1989) [87] & Air-water, air-water-magnetic & $h_{c, \max }=0.12\left(\frac{\rho g^{2}}{\mu}\right)^{\frac{1}{6}}\left(\frac{\rho-\rho_{g}}{\rho}\right)^{\frac{1}{3}}\left(k \rho c_{p}\right)^{\frac{1}{2}}$ & $\begin{array}{l}\text { For a cylindrical probe immersed in a } \\
\text { bubble column and } u_{g}=0.015-0.333 \mathrm{~m} / \mathrm{s} \text {. }\end{array}$ \\
\hline 11 & $\begin{array}{l}\text { Chen and Mayinger } \\
\text { (1992) [79] }\end{array}$ & Ethanol, propanol, R113 an water & $\begin{array}{l}\mathrm{Nu}=0.6 \operatorname{Re}^{0.6} \operatorname{Pr}^{0.5} \\
\mathrm{Nu}=0.185 \operatorname{Re}^{0.7} \operatorname{Pr}^{0.5}\end{array}$ & $\begin{array}{l}\text { At the moment of detachment: } \\
\text { The 1st correlation is for bubble growing } \\
\text { period (formation). } \\
\text { The 2nd correlation is for bubble collapsing } \\
\text { period (bubble raising). }\end{array}$ \\
\hline 12 & Yang et al. (2000) [31] & $\begin{array}{l}\text { Nitrogen-Paratherm NF heat transfer } \\
\text { fluid-glass beads }\end{array}$ & St $=0.037\left[\operatorname{ReFrPr} \operatorname{Pr}^{1.87}\left(\frac{\varepsilon_{g}^{\prime}}{1-\varepsilon_{g}^{\prime}}\right)\right]^{-0.22}$ & $\begin{array}{l}\text { For slurry bubble columns with } \\
\mathrm{P} \leq 4.2 \mathrm{MPa} \& \mathrm{~T} \leq 81^{\circ} \mathrm{C} \text {. }\end{array}$ \\
\hline 13 & Cho et al. (2002) [88] & Air-viscous fluid & $h_{c}=11710 u_{g}^{0.445} \mu_{l}^{-0.06} P^{0.176}$ & $\begin{array}{l}\text { For pressurizedbubble columns with gas } \\
\text { velocity }=0-0.12 \mathrm{~m} / \mathrm{s} \\
\text { pressure }=0.1-0.6 \mathrm{MPa} \& \text { liquid } \\
\text { viscosity }=1-38 \mathrm{mPa} . \mathrm{s}\end{array}$ \\
\hline 14 & Lee et al. (2003) [89] & R11 & $Q=\dot{m} h_{f g}=4 \pi \rho_{v} h_{f g} R^{2} \frac{d R}{d t}$ & $\begin{array}{l}\text { For partial nucleate boiling on the constant } \\
\text { wall temperature microscale heater. }\end{array}$ \\
\hline 15 & $\begin{array}{l}\text { Jhawar and Prakash } \\
\text { (2007) [34] }\end{array}$ & Air-tap water & $\begin{array}{l}h_{c}=8.65\left[\frac{u_{g}}{\epsilon_{g}}\right]+1.32 \\
h_{c}=2\left[\frac{u_{g}}{\epsilon_{g}}\right]+3.3\end{array}$ & $\begin{array}{l}\text { For bubble column using a fine and a } \\
\text { coarse gas distributor: } \\
\text { The 1st correlation is for } \frac{u_{g}}{\epsilon_{g}} \leq 0.3 \mathrm{~m} / \mathrm{s} \\
\text { The } 2 \text { nd correlation is for } \frac{u_{g}}{\epsilon_{g}}>0.3 \mathrm{~m} / \mathrm{s} \text {. }\end{array}$ \\
\hline 16 & Leong et al. (2017) [90] & & $\begin{aligned} q^{\prime \prime}=h_{f g} \rho_{g}^{\frac{1}{2}}\left[\sigma\left(\rho_{l}-\right.\right. & \left.\left.\rho_{v}\right)\right]^{\frac{1}{4}}\left[\frac{1+\cos \beta}{16}\right] \\
& \times\left[\frac{2}{\pi}(1-\sqrt{\phi}) \frac{r+\cos \beta}{1+\cos \beta}\right. \\
& \left.+\frac{\pi}{4}(1-\sqrt{\phi})^{\frac{1}{2}}\left(1+\cos \beta^{\prime \prime}\right) \cos \phi^{\prime}\right]^{\frac{1}{2}}\end{aligned}$ & $\begin{array}{l}\text { Critical heat flux for pool boiling by } \\
\text { adopting the force balance approach } \\
\text { including the effects of capillary wicking } \\
\text { force and the modified Taylor wavelength. }\end{array}$ \\
\hline
\end{tabular}




\subsection{Computational Simulations}

Two-phase flow analysis usually starts with general principles that govern all matter behavior in a particular mass, momentum, and energy conservation, because they can be expressed in mathematical form at any time and in any position [91]. Additionally, Wallis [64] is considered to be the first scientist who used the one-dimensional drift flux to analyze the fluid flow.

Several studies focused on simulating bubble columns. Indeed, different computational fluid dynamics methods were used to study the bubble column hydro-dynamically. For example, Direct Numerical Simulations (DNS) represent the whole physics of the flow, using the Volume of Fluid (VOF) approach in software such as FLUENT [92], and OpenFOAM [93]. Therefore, special algorithms are necessary for fluid interfaces, tracing between continuous and particle, as well as a very fine mesh grid to garner all time and length scales.

The interface motion can be modeled using different methods [94]. For example, such methods include the Eulerian-Lagrangian (E-L) method, the two-dimensional and transient study of a single particle [95], and the Eulerian-Eulerian (E-E) method. Different turbulence models adopted the E-E method, such as the Reynolds Stress Model (RSM), large eddy simulation [96], explicit algebraic Reynolds stress model, baseline models [97], and multi-fluid turbulence model [78]. By solving the motion equations for individual bubbles, or bubble tracking, the gas phase can be described [98].

For the wet scrubber, there is currently no simulation available due to the complex churn-turbulent flow, and its extremely complex design compared to a bubble column. As a starting point, simulation for simple cases of flow inside a wet scrubber can be achieved using ANSYS Fluent with several assumptions included.

\section{Conclusions}

The performance of a diesel exhaust wet scrubber depends on several parameters, including the scrubber design and operating conditions. It is important to reduce the humidity at the scrubber exit, to prolong the DPF life after the scrubber. This will produce two benefits: increasing the operating time, and reducing the maintenance cost. Few studies have focused on this type of wet scrubber. Therefore it is advantageous to have an up-to-date and informative database about this device, in particular for countries with mining sites, or which have mining equipment production. To reduce the time that might be spent on such studies, careful consideration of bubble column studies should be made to find the most suitable investigative approach, especially using computational simulation, as wet scrubbers have almost the same design and operating principles as bubble columns. Finally, experiments and three appropriately-developed models, thermodynamics, heat transfer, and computational simulation, can be used to investigate the performance of diesel exhaust wet scrubbers.

Author Contributions: Conceptualization, A.A.A. and R.S.; Methodology, A.A.A. and R.S.; Resources, A.A.A.; Writing-Original Draft Preparation, A.A.A.; Writing-Review \& Editing, A.A.A., R.S., and R.J.B.

Conflicts of Interest: The authors declare no conflict of interest. 


\section{Nomenclature}

A Surface area $\left(\mathrm{m}^{2}\right) \quad Z$

$A R \quad$ Aspect ratio

a Bubble acceleration $\left(\mathrm{m} / \mathrm{s}^{2}\right)$

Bo Bond number $\quad \beta$

C Component concentration

$C_{D} \quad$ Drag coefficient

$c_{p} \quad$ Specific heat $(\mathrm{kJ} / \mathrm{kg} \cdot \mathrm{K})$

DPF Diesel Particulate Filter

d Bubble diameter $(\mathrm{m})$

E Evaporation rate $(\mathrm{kg} / \mathrm{s})$

$\dot{E} \quad$ Energy $(\mathrm{kW})$

Ec Eckert number

e

F

$g$

$h$

$h_{c}$

$k$

$k_{v}$

LLSP

$m$.

$\mathrm{Nu}$

$n$

$n b$

$P$

Pe

PM

Pr

$Q$

$Q^{\prime}$

$q$

$q^{\prime \prime}$

$R$

$R^{\prime}$

$R^{\prime \prime}$

$\operatorname{Re}$

ROS

RSM

sa

SMPS

St

SVR

$T$

TEOM Tapered Element Oscillating Microbalance

$t$

$u$

V

VOF

$W$

We

X

$$
\text { Internal energy }(\mathrm{kJ} / \mathrm{kg})
$$

Force (N)

Gravity acceleration $\left(\mathrm{m} / \mathrm{s}^{2}\right)$

Fluid enthalpy $(\mathrm{kJ} / \mathrm{kg})$

Heat transfer coefficient $\left(\mathrm{W} / \mathrm{m}^{2} \cdot \mathrm{K}\right)$

Fluid thermal conductivity $(\mathrm{W} / \mathrm{m} \cdot \mathrm{K})$

Velocity factor

Laser Light Scattering Photometry

Mass flow rate $(\mathrm{kg} / \mathrm{s})$

Nusselt number

Bubble frequency

The number of bubbles

Pressure (kPa)

\section{Peclet number}

\section{Particulate Matter}

Prandtl number

\section{Heat transfer $(\mathrm{kW})$}

Average volumetric flow rate $\left(\mathrm{m}^{3} / \mathrm{s}\right)$

$$
\text { Heat transfer per kilogram }(\mathrm{kW} / \mathrm{kg})
$$

Heat flux $\left(\mathrm{W} / \mathrm{m}^{2}\right)$

Bubble radius ( $\mathrm{m}$ )

The curvature radius of a lenticular body $(\mathrm{m})$

$$
\text { Bubble radial velocity }(\mathrm{dR} / \mathrm{dt})
$$

$$
\text { Reynolds number }
$$

$$
\text { Reynolds Stress Model }
$$

$$
\text { Bubble front face area }\left(\mathrm{m}^{2}\right)
$$

\section{Scanning Mobility Particle Sizer}

$$
\text { Stanton number }
$$

\section{Support Vector Regression}

$$
\text { Temperature (K) }
$$

\section{Time (s)}

The fluid velocity $(\mathrm{m} / \mathrm{s})$

$$
\text { Volume }\left(\mathrm{m}^{3}\right)
$$

$$
\text { Volume of Fluid }
$$

$$
\text { Water weight }(\mathrm{kg})
$$

$$
\text { Weber number }
$$

$$
\text { Bubble horizontal position }
$$

Reactive Oxygen Species

\section{Bubble vertical position}

\section{Greek letters}

Fluid thermal diffusivity $\left(\mathrm{m}^{2} / \mathrm{s}\right)$

Dimensionless radius $\left(\mathrm{R} / \mathrm{R}_{0}\right)$

Dimensionless constant

Contact angle $\left({ }^{\circ}\right)$

Thermal expansion coefficient $(1 / \mathrm{K})$

Changes

Dissipation rate $\left(\mathrm{m}^{2} / \mathrm{s}^{3}\right)$

Hold-up

Removal efficiency (\%)

Latent heat of evaporation $(\mathrm{kJ} / \mathrm{kg})$

The fluid drop internal viscosity (mPa.s)

Fluid kinematic viscosity $\left(\mathrm{m}^{2} / \mathrm{s}\right)$

The density of the fluid $\left(\mathrm{kg} / \mathrm{m}^{3}\right)$

Surface tension $(\mathrm{N} / \mathrm{m})$

Dimensionless time

Volume fraction in slurry phase

Surface orientation $\left(^{\circ}\right)$

\section{Subscript}

Above water surface

Bubble

Below water surface

Carbon dioxide

Drag

Equivalent

Liquid

Gravity

Gas

Water or water vapour

Sequence

Inlet

Condensation

Lost

Liquid

Mixture

Maximum value

Nitrogen

Oxygen

Outlet

Relative

Small bubble

Terminal

Transition regime

Virtual

Vapour or gas

Wet scrubber storage

Water volume changing

Initial value

Bubble surrounding fluid 


\section{References}

1. Ristovski, Z.D.; Miljevic, B.; Surawski, N.C.; Morawska, L.; Fong, K.M.; Goh, F.; Yang, I.A. Respiratory health effects of diesel particulate matter. Respirology 2012, 17, 201-212. [CrossRef] [PubMed]

2. Giechaskiel, B.; Suarez-Bertoa, R.; Lahde, T.; Clairotte, M.; Carrier, M.; Bonnel, P.; Maggiore, M. Evaluation of NOx emissions of a retrofitted euro 5 passenger car for the horizon prize "Engine retrofit". Environ. Res. 2018, 166, 298-309. [CrossRef] [PubMed]

3. Giechaskiel, B.; Schwelberger, M.; Delacroix, C.; Marchetti, M.; Feijen, M.; Prieger, K.; Andersson, S.; Karlsson, H. Experimental assessment of solid particle number Portable Emissions Measurement Systems (PEMS) for heavy-duty vehicles applications. J. Aerosol Sci. 2018, 123, 161-170. [CrossRef]

4. Giechaskiel, B. Solid particle number emission factors of euro VI heavy-duty vehicles on the road and in the laboratory. Int. J. Environ. Res. Public Health 2018, 15, 304. [CrossRef] [PubMed]

5. Giechaskiel, B.; Clairotte, M.; Valverde-Morales, V.; Bonnel, P.; Kregar, Z.; Franco, V.; Dilara, P. Framework for the assessment of PEMS (Portable Emissions Measurement Systems) uncertainty. Environ. Res. 2018, 166, 251-260. [CrossRef] [PubMed]

6. Miljevic, B. The Application of a Profluorescent Nitroxide Probe to Detect Reactive Oxygen Spices Derived from Combustion-Generated Particulate Matter. Ph.D. Thesis, Queensland University of Technology, Brisbane City, Australia, 2010.

7. Rao, V.; Dayawansa, D.; Honnery, D. Reducing Diesel Particulate Matter in Underground Mines by Optimising Design and Operation of Diesel Exhaust Systems. Available online: https: / www.acarp.com.au/ abstracts.aspx?repId=C23013 (accessed on 19 September 2018).

8. Volkwein, J.C.; Mischler, S.E.; Davies, B.; Ellis, C. Field measurement of diesel particulate matter emissions. Ann. Occup. Hyg. 2008, 52, 99-105. [CrossRef] [PubMed]

9. Gaffney, J.S.; Marley, N.A. The impacts of combustion emissions on air quality and climate-From coal to biofuels and beyond. Atmos. Environ. 2009, 43, 23-36. [CrossRef]

10. Giakoumis, E.G.; Dimaratos, A.M.; Rakopoulos, C.D.; Rakopoulos, D.C. Combustion instability during starting of turbocharged diesel engine including biofuel effects. J. Energy Eng. 2017, 143, 1-15. [CrossRef]

11. Pratt, S.; Grainger, A.; Jones, L.; Todd, J.; Brennan, R. Diesel Vehicle Research at BHP Collieries. Available online: https: / / ro.uow.edu.au/cgi/viewcontent.cgi?referer=https:/ /www.google.com.tw / \&httpsredir= $1 \&$ article $=1274 \&$ context $=$ coal (accessed on 23 May 2018).

12. Papagiannakis, R.G.; Hountalas, D.T.; Krishnan, S.R.; Srinivasan, K.K.; Rakopoulos, C.D.; Rakopoulos, D.C. Numerical evaluation of the effects of compression ratio and diesel fuel Injection timing on the performance and emissions of a fumigated natural gas-diesel dual-fuel engine. J. Energy Eng. 2016, 142, 1-16. [CrossRef]

13. Suarez-Bertoa, R.; Kousoulidou, M.; Clairotte, M.; Giechaskiel, B.; Nuottimäki, J.; Sarjovaara, T.; Lonza, L. Impact of HVO blends on modern diesel passenger cars emissions during real world operation. Fuel 2019, 235, 1427-1435. [CrossRef]

14. Rakopoulos, D.C.; Rakopoulos, C.D.; Giakoumis, E.G. Impact of properties of vegetable oil, bio-diesel, ethanol and n-butanol on the combustion and emissions of turbocharged HDDI diesel engine operating under steady and transient conditions. Fuel 2015, 156, 1-19. [CrossRef]

15. Cardenas, M.D.; Armas, O.; Mata, C.; Soto, F. Performance and pollutant emissions from transient operation of a common rail diesel engine fueled with different biodiesel fuels. Fuel 2016, 185, 743-762. [CrossRef]

16. Mata, C.; Gómez, A.; Armas, O. The influence of ethanol-diesel blend on pollutant emissions from different bus fleets under acceleration transitions. Fuel 2017, 209, 322-328. [CrossRef]

17. Rakopoulos, D.C.; Rakopoulos, C.D.; Giakoumis, E.G.; Komninos, N.P.; Kosmadakis, G.M.; Papagiannakis, R.G. Comparative evaluation of ethanol, n-butanol, and diethyl ether effects as biofuel supplements on combustion characteristics, cyclic variations, and emissions balance in light-duty diesel engine. J. Energy Eng. 2017, 143, 1-8. [CrossRef]

18. Diesel Particulate Matter \& Occupational Health Issues. Available online: http://www.gastech.com.au/ files/dpm/Diesel-Particulate-Matter-and-Occupational-Health-Issues.pdf (accessed on 26 January 2017).

19. Mussatti, D.; Hemmer, P. Wet Scrubbers for Particulate Matter. Available online: https://www3.epa.gov / ttncatc1/dir1/cs6ch2.pdf (accessed on 22 December 2017). 
20. Situ, R.; Brown, R.J.; Wang, H.; Surawski, N.; Ristovski, Z.D. Exit humidity of wet scrubbers for underground coal mines. In Proceedings of the 18th Australasian Fluid Mechanics Conference, Launceston, Australia, 3-7 December 2012.

21. Youssef, A.A. Fluid Dynamics and Scale-Up of Bubble Columns with Internals. Ph.D. Thesis, Washington University in St. Louis, Washington, DC, USA, 2010.

22. Shaikh, A.; Al-Dahhan, M.H. A review on flow regime transition in bubble columns. Int. J. Chem. React. Eng. 2007, 5, 1-68. [CrossRef]

23. Gabriel, D.; Cox, H.H.J.; Deshusses, M.A. Conversion of full-scale wet scrubbers to biotrickling filters for $\mathrm{H}_{2} \mathrm{~S}$ control at publicly owned treatment works. J. Environ. Eng. 2004, 130, 1110-1117. [CrossRef]

24. Barbour, W.; Oommen, R.; Shareef, G.S.; Corporation, R.; Vatavuk, W.M. Post-Combustion Controls. Section 5. Available online: https://www3.epa.gov/ttn/ecas/docs/cs5-2ch1.pdf (accessed on 22 December 2017).

25. Azzopardi, B.; Zhao, D.; Yan, Y.; Morvan, H.; Mudde, R.F.; Lo, S. Hydrodynamics of Gas-Liquid Reactors; Wiley: Hobbken, NJ, USA, 2011.

26. Bai, W. Experimental and Numerical Investigation of Bubble Column Reactors. Ph.D. Thesis, Eindhoven University of Technology, Eindhoven, The Netherlands, 2010.

27. Meikap, B.C.; Kundu, G.; Biswas, M.N. Modeling of a novel multi-stage bubble column scrubber for flue gas desulfurization. Chem. Eng. J. 2002, 86, 331-342. [CrossRef]

28. Besagni, G.; Inzoli, F.; Ziegenhein, T. Two-phase bubble columns: A comprehensive review. Chem. Eng. 2016, 2, 13. [CrossRef]

29. Davidson, J.F.; Schüler, B.O.G. Bubble formation at an orifice in a viscous liquid. Ins. Chem. Eng. 1997, 75, 105-115. [CrossRef]

30. Lienhard, J.H.; Lienhard, J.H. A Heat Transfer Text Book, 4th ed.; Phlogiston Press: Cambridge, MA, USA, 2011.

31. Yang, G.Q.; Luo, X.; Lau, R.; Fan, L.S. Heat-transfer characteristics in slurry bubble columns at elevated pressures and temperatures. Ind. Eng. Chem. 2000, 39, 2568-2577. [CrossRef]

32. Harris, P.J.; Al-Awadi, H.; Soh, W.K. An investigation into the effects of heat transfer on the motion of a spherical bubble. ANZIAM J. 2004, 45, 361-371. [CrossRef]

33. Gandhi, A.B.; Joshi, J.B. Estimation of heat transfer coefficient in bubble column reactors using support vector regression. Chem. Eng. J. 2010, 160, 302-310. [CrossRef]

34. Jhawar, A.K.; Prakash, A. Analysis of local heat transfer and hydrodynamics in a bubble column using fast response probes. Chem. Eng. J. 2007, 62, 7274-7281. [CrossRef]

35. Thakre, S.S.; Joshi, J.B. CFD simulation of bubble column reactors: Importance of drag force formulation. Chem. Eng. Sci. 1999, 54, 5055-5060. [CrossRef]

36. Deckwer, W.D.; Loulsl, Y.; Zaldl, A.; Ralek, M. Hydrodynamic properties of the Fischer-Tropsch slurry process. Ind. Eng. Chem. Process Des. Dev. 1980, 19, 699-708. [CrossRef]

37. Kurella, S.; Balla, M.; Bhukya, P.K. Scrubbing of $\mathrm{HCl}$ gas from synthesis gas in a multistage dual-flow sieve plate wet scrubber by alkaline solution. J. Chem. Eng. Process Technol. 2015, 6, 1-7. [CrossRef]

38. Walsh, M.A. Overview of Basic Types and Configuration of Wet Scrubber Technologies. Available online: http://wpca.info/pdf/presentations/Eskom2007/2)Overview\%20of\%20Basic\%20Types\%20\& \%20Config\%20of\%20WFGD\%20by\%20Mike\%20Walsh-Marsulex.pdf (accessed on 17 September 2018).

39. Hoque, N.; Situ, R.; Hagan, W.; Almedia, J.; Lin, W.; Brown, R.J. A thermo-fluid study of a diesel engine wet scrubber. In Proceedings of the 19th Australasian Fluid Mechanics Conference, Melbourne, Australia, 8-11 December 2014.

40. Wang, T.; Wang, J.; Jin, Y. Theoretical prediction of flow regime transition in bubble columns by the population balance model. Chem. Eng. Sci. 2005, 60, 6199-6209. [CrossRef]

41. Higuera, F.J.; Medina, A. Injection and coalescence of bubbles in a quiescent inviscid liquid. Eur. J. Mech. B/Fluids 2006, 25, 164-171. [CrossRef]

42. Van Rens, G.L.M.A.; de Wilde, H.P.J. Pre- and After-Treatment Techniques for Diesel Engines in Inland Navigation. Available online: https:/ / www.ecn.nl/publicaties/PdfFetch.aspx?nr=ECN-RX--05-175 (accessed on 26 January 2017).

43. Lin, T.; Fan, L. Heat transfer and bubble characteristics from a nozzle in high-pressure bubble columns. Chem. Eng. Sci. 1999, 54, 4853-4859. [CrossRef]

44. Talaia, M.A.R. Terminal velocity of a bubble rise in a liquid column. World Acad. Sci. Eng. Technol. 2007, 28, 264-268. 
45. Rao, V.; Dayawansa, D.; Honnery, D.; Sharman, S.; Garnier, G.; Curcio, P. Extending the Life of Disposable Exhaust Filters in Vehicles Operating in Underground Coal Mines; ACARP Report C21017; Monash University: Melbourne, Australia, 2013.

46. Burtscher, H. Physical characterization of particulate emissions from diesel engines: A review. J. Aerosol Sci. 2005, 36, 896-932. [CrossRef]

47. Bandyopadhyay, A.; Biswas, M.N. Fly-ash scrubbing in a tapered bubble column scrubber. Process Saf. Environ. Prot. 2006, 84, 54-62. [CrossRef]

48. Guo, R.; Gao, X. Simultaneous removal of $\mathrm{SO}_{2}$ and $\mathrm{NO}_{2}$ by wet scrubbing using aqueous limestone slurry. In Proceedings of the 11th International Conference on Electrostatic Precipitation, Hangzhou, China, 20-24 October 2008; pp. 602-605.

49. Bhadra, V.; Singh, H.K.; Kahndelwal, G.; Kumar, A. Effect of flue gases with wet scrubber in 4-stroke C.I engine. Int. J. Sci. Eng. Technol. 2014, 2, 1422-1430.

50. Van Setten, B.A.A.L.; Makkee, M.; Moulijn, J.A. Science and technology of catalytic diesel particulate filters. Catal. Rev. 2001, 43, 489-564. [CrossRef]

51. Tokumura, M.; Mizukoshi, A.; Noguchi, M.; Wada, Y.; Usami, Y.; Yamaki, T.; Yanagisawa, Y. Removal of acetaldehyde gas using wet scrubber coupled with photo-Fenton reaction. AIMS Environ. Sci. 2016, 3, 159-167. [CrossRef]

52. Huang, W. Homogeneous and Heterogeneous Fenton and Photo-Fenton Processes: Impact of Iron Complexing Agent Ethylenediamine- $N, N^{\prime}$-disuccinic Acid (EDDS). Available online: https:/ / tel.archivesouvertes.fr/tel-00788822/document (accessed on 18 September 2018).

53. Machulek, A.; Quina, F.H.; Gozzi, F.; Silva, V.O.; Friedrich, L.C.; Moraes, J.E.F. Fundamental Mechanistic Studies of the Photo-Fenton Reaction for the Degradation of Organic Pollutants. Available online: https: / / www.intechopen.com/books/organic-pollutants-ten-years-after-the-stockholm-conventionenvironmental-and-analytical-update/fundamental-mechanistic-studies-of-the-photo-fenton-reactionfor-the-degradation-of-organic-pollutan (accessed on 13 September 2018).

54. Ebrahiem, E.E.; Al-Maghrabi, M.N.; Mobarki, A.R. Removal of organic pollutants from industrial wastewater by applying photo-Fenton oxidation technology. Arab. J. Chem. 2017, 10, S1674-S1679. [CrossRef]

55. D'Addio, L.; Natale, F.D.; Carotenuto, C.; Scoppa, G.; Dessy, V.; Lancia, A. Removal of Fine and Ultrafine Combustion Derived Particles in a Wet Electrostatic Scrubber. Available online: http:/ /www.combustioninstitute.it/proceedings / XXXVI-ASICI/papers/36proci2013.VI4.pdf (accessed on 12 July 2017).

56. DeGuzman, N.M.; Chato, J.C. Evaporative Heat Transfer Characteristics in a Vertical Channel with Obstructions. Available online: https://core.ac.uk/download/pdf/4820839.pdf (accessed on 18 September 2018).

57. Ishii, M.; Hibiki, T. Thermo-Fluid Dynamics of Two-Phase Flow; Springer: New York, NY, USA, 2006.

58. Wang, H.Y.; Dong, F. A method for bubble volume calculating in vertical two-phase flow. J. Phys. Conf. Ser. 2009, 147, 1-12. [CrossRef]

59. $\mathrm{Xu}, \mathrm{Y}$. Direct Contact Condensation with and Without Noncondensable Gas in a Water Pool. Ph.D. Thesis, Purdue University, West Lafayette, IN, USA, 2004.

60. Levich, V.G. Physiochemical Hydrodynamics; Prentice-Hall: Englewood Cliffs, NJ, USA, 1962.

61. Martínez-Bazán, C.; Montañéz, J.L.; Lasheras, J.C. On the breakup of an air bubble injected into a fully developed turbulent flow: I: Breakup frequency. J. Fluid Mech. 1999, 401, 157. [CrossRef]

62. Davidson, J.F.; Schüler, B.O.G. Bubble formation at an orifice in an inviscid liquid. Trans. Inst. Chem. Eng. 1960, 38, 335-342.

63. Leibson, I.; Holcomb, E.G.; Cacoso, A.G.; Jacmic, J.J. Formation from single orifices. AIChE J. 1956, 2, $296-306$. [CrossRef]

64. Wallis, G.B. One-Dimensional Two-Phase Flow; McGraw-Hill: New York, NY, USA, 1969.

65. Moalem, D.; Sideman, S. The effect of motion on bubble collapse. Int. J. Heat Mass Trans. 1973, 16, $2321-2329$. [CrossRef]

66. Anagbo, P.E. Formation of ellipsoidal bubbles at free-standing nozzle. Chem. Eng. Sci. 1991, 46, 781-788. [CrossRef]

67. Lehr, F.; Mewes, D. A transport equation for the interfacial area density applied to bubble columns. Chem. Eng. Sci. 2001, 56, 1159-1166. [CrossRef] 
68. Zhang, L.; Yang, C.; Mao, Z. Unsteady motion of a single bubble in highly viscous liquid and empirical correlation of drag coefficient. Chem. Eng. Sci. 2008, 63, 2099-2106. [CrossRef]

69. Parkinson, L.; Sedev, R.; Fornasiero, D.; Ralston, J. The terminal rise velocity of 10-100 $\mu \mathrm{m}$ diameter bubbles in water. J. Colloid Interface Sci. 2008, 322, 168-172. [CrossRef] [PubMed]

70. Raymond, F.; Rosant, J.M. A numerical and experimental study of the terminal velocity and shape of bubbles in viscous liquids. Chem. Eng. Sci. 2000, 55, 943-955. [CrossRef]

71. Kantarci, N.; Borak, F.; Ulgen, K.O. Bubble column reactors. Process Biochem. 2005, 40, 2263-2283. [CrossRef]

72. Davies, R.M.; Taylor, G. The mechanics of large bubbles rising through liquids in tubes. Proc. R. Soc. 1950, 375-390. [CrossRef]

73. Krishna, R.; Swart, J.W.A.D.; Hennephof, D.E.; Ellenberger, J.; Hoefsloot, H.C.J. Influence of increased gas density on hydrodynamics of bubble column reactors. AIChE J. 1994, 40, 112-121. [CrossRef]

74. Delnoij, E.; Lammers, F.A.; Kuipers, J.A.M.; van Swaaij, W.P.M. Dynamic simulation of dispersed gas-liquid two-phase flow using a discrete bubble model. Chem. Eng. Sci. 1997, 52, 1429-1458. [CrossRef]

75. Tomiyama, A.; Kataoka, I.; Zun, I.; Sakaguchi, T. Drag coefficients of single bubbles under normal and micro gravity conditions. JSME Int. J. Ser. B 1998, 41, 472-479. [CrossRef]

76. Tomiyama, A.; Celata, G.P.; Hosokawa, S.; Yoshida, S. Terminal velocity of single bubbles in surface tension force dominant regime. Int. J. Multiph. Flow 2002, 28, 1497-1519. [CrossRef]

77. Chen, P. Modeling the Fluid Dynamics of Bubble Column Flows. Ph.D. Thesis, Washington University, Washington, DC, USA, 2004.

78. Abd Ali, M.K. CFD Simulation of bubbly flow through a bubble column. Int. J. Sci. Eng. Res. 2014, 5, 904-910.

79. Chen, Y.M.; Mayinger, F. Measurement of heat transfer at the phase interface of condensing bubbles. Int. J. Multiph. Flow 1992, 18, 877-890. [CrossRef]

80. Fair, J.R.; Lambright, A.J.; Andersen, J.W. Heat transfer and gas holdup in a sparged contactor. I EC Process Des. Dev. 1962, 1, 33-36. [CrossRef]

81. Mikic, B.B.; Rohsenow, M.W. A new correlation of pool-boiling data including the effect of heating surface characteristics. J. Heat Trans. 1969, 9, 245-250. [CrossRef]

82. Moalem, D.; Sideman, S. Bubble condensation with non-homogeneous distribution of non-condensables. Int. J. Heat Mass Trans. 1971, 14, 2152-2156. [CrossRef]

83. Theofanous, T.G.; Fauske, H.K. The effect of noncondensables on the rate of sodium vapor condensation from a single-rising HCDA bubble. Nucl. Technol. 1973, 19, 132-139. [CrossRef]

84. Hart, W.F. Heat transfer in bubble-agitated system. A general correlation. Ind. Eng. Chem. Process Des. 1976, 15, 109-114. [CrossRef]

85. Ozisik, M.N.; Kress, T.S. Effects of internal circulation velocity and noncondensable gas on vapor condensation from a rising bubble. Nucl. Sci. Eng. 1978, 66, 397-405. [CrossRef]

86. Hikita, H.; Asal, S.; Klkukawa, H.; Zalke, T.; Ohue, M. Heat transfer coefficient in bubble columns. Am. Chem. Soc. 1981, 20, 540-545. [CrossRef]

87. Saxena, S.C. Heat transfer from a cylindrical probe immersed in a bubble column. Chem. Eng. J. 1989, 41, 25-39. [CrossRef]

88. Cho, Y.J.; Woo, K.J.; Kang, Y.; Kim, S.D. Dynamic characteristics of heat transfer coefficient in pressurized bubble columns with viscous liquid medium. Chem. Eng. Process. 2002, 41, 699-706. [CrossRef]

89. Lee, H.C.; Oh, B.D.; Bae, S.W.; Kim, M.H.; Lee, J.Y.; Song, I.S. Partial nucleate boiling on the microscale heater maintaining constant wall temperature. J. Nucl. Sci. Technol. 2003, 40, 768-774. [CrossRef]

90. Leong, K.C.; Ho, J.Y.; Wong, K.K. A critical review of pool and flow boiling heat transfer of dielectric fluids on enhanced surfaces. Appl. Therm. Eng. 2017, 112, 999-1019. [CrossRef]

91. Munkejord, S.T.; Jakobsen, J.P.; Austegard, A.; Molnvik, M.J. Thermo- and fluid-dynamical modelling of two-phase multi-component carbon dioxide mixtures. In Proceedings of the 9th International Conference on Greenhouse Gas Control Technologies, Washington, DC, USA, 16-20 November 2008.

92. Akhtar, A. CFD Simulations for continuous flow of bubbles through gas-liquid columns: Application of VOF Method. Chem. Prod. Process Model. 2007, 2, 1-19. [CrossRef]

93. Andras, H.; Christian, J.; Michael, L.; Christia, K.; Aleksander, M.; Michael, H. CFD Simulation of bubble columns using the VOF model: comparison of commercial and open source solvers with an experiment. Chem. Eng. Trans. 2009, 18. [CrossRef] 
94. Khan, K.I. Fluid Dynamic Modelling of Bubble Column Reactor. Ph.D. Thesis, Politecnico di Torino, Turin, Italy, 2014.

95. Lapin, A.; Lübbert, A. Numerical simulations of the dynamics of two-phase gas-liquid flows in bubble columns. Chem. Eng. Sci. 1994, 49, 3661-3674. [CrossRef]

96. Ekambara, K.; Dhotre, M.T. CFD Simulation of bubble column. Nucl. Eng. Des. 2010, 240, 963-969. [CrossRef]

97. Masood, R.M.A.; Rauh, C.; Delgado, A. CFD Simulation of bubble column flows: An explicit algebraic Reynolds stress model approach. Int. J. Multiph. Flow 2014, 66, 11-25. [CrossRef]

98. Monahan, S.M. Computational Fluid Dynamics Analysis of Air-Water Bubble Columns. Ph.D. Thesis, Iowa State University, Ames, IA, USA, 2007.

2018 by the authors. Licensee MDPI, Basel, Switzerland. This article is an open access article distributed under the terms and conditions of the Creative Commons Attribution (CC BY) license (http://creativecommons.org/licenses/by/4.0/). 